\section{Tolerance of Watermelon Seedlings to Low-temperature Chilling Injury}

Elzbieta U. Kozik

Institute of Horticulture, Department of Genetics, Breeding and Biotechnology of Vegetable Crops, 96-100 Skierniewice, Poland

Todd C. Wehner ${ }^{1}$

Department of Horticultural Science, North Carolina State University, Raleigh, NC 27695-7609

Additional index words. chilling, Citrullus lanatus, cold resistance, plant breeding, stress resistance, vegetable crops, watermelon

\begin{abstract}
Watermelon [Citrullus lanatus (Thunb.) Matsum. \& Nakai] is one of the Cucurbitaceae species and subtropical crops that exhibit chilling injury (CI) when exposed to low temperatures. Watermelon seedlings were tested for chilling tolerance using methods modified from cucumber. Three experiments were conducted using different combinations of chilling durations of $6,12,24$, or 36 hours and chilling temperatures of 2 or $4{ }^{\circ} \mathrm{C}$. Watermelon seedlings were more resistant to low temperatures than cucumber seedlings, so it was necessary to use long chilling durations to induce significant foliar damage. A diverse set of 16 watermelon cultigens was tested: Allsweet, Black Diamond, Chubby Gray, Charlee, Charleston Gray, Dixielee, Golden, Golden Honey, New Winter, NH Midget, Sugar Baby, Sugarlee, Sunshade, PI 189225, PI 244018, and PI 595203. Experiments were conducted in a controlled environment with a light intensity of $500 \mathrm{mmol} \cdot \mathrm{m}^{-2} \cdot \mathrm{s}^{-1}$ photosynthetic photon flux density (PPFD). Optimal conditions for chilling treatment were 36 hours at $4{ }^{\circ} \mathrm{C}$ or 24 hours at $2^{\circ} \mathrm{C}$. The most resistant cultigen was PI 244018, and the most susceptible cultigens were NH Midget and Golden.
\end{abstract}

North Carolina is the seventh leading state in watermelon [Citrullus lanatus (Thunb.) Matsum. \& Nakai] production and value in the United States (Arney et al., 2006). Watermelon is second to cucumber (Cucumis sativus L.) in cucurbit area planted in North Carolina (North Carolina Department of Agriculture and Consumer Services, 2004). The land devoted to watermelon production in North Carolina from 1994 to 2004 ranged from 3238 to 4616 ha (Arney et al., 2006).

Temperatures below $10{ }^{\circ} \mathrm{C}$ may injure tropical and subtropical crops such as species of the Cucurbitaceae (Raison, 1974). The damage is often referred to as CI and was reviewed by Lyons (1973). There have been several reports on chilling tolerance in cucumber seedlings (Chung et al., 2003; Kozik et al., 2007; Kozik and Wehner, 2008; Smeets and Wehner, 1997), but not watermelon seedlings.

Chilling damage in cucumber, like in other thermophylic plants, depends mainly on chilling temperature, duration of chilling, and on light intensity during chilling (Minchin and Simon, 1973; Rietze, 1988; Rietze and Wiebe, 1987, 1989; Van Hasselt, 1972; Wang, 1986; Wright and Wilson, 1973). The environment before and after chilling also is important. Chilling damage is affected by the temperature, light conditions, and water status of the plants before chilling (Lafuente

Received for publication 4 Sept. 2013. Accepted for publication $3 \mathrm{Jan} .2014$.

${ }^{1}$ To whom reprint requests should be addressed; e-mail todd_wehner@ncsu.edu. et al., 1991; Pomeroy and Mudd, 1987; Rietze and Wiebe, 1989; Rikin et al., 1976; Saltveit, 1991; Wilson and Crawford, 1974) and the light conditions after chilling (Lasley et al., 1979; Rietze and Wiebe, 1989). Watermelon is susceptible to CI but is more resistant than cucumber (Wehner and Mirdad, 1994).

Low-temperature effects have been studied on germination, seedling damage, and fruit damage in cucurbits. For example, there is genetic variation among cucumber cultigens for germination at low temperature (Lower, 1974; Nienhuis et al., 1983; Wehner, 1981). Cold germination has a heritability of 0.15 to 0.61 , depending on test temperature and population used (Wehner, 1982, 1984), and can be improved without correlated changes in other important horticultural traits (Staub et al., 1988). Genetic variation for chilling tolerance in cucumber exists (Aoki et al., 1988, 1989; Cabrera et al., 1992; Liu et al., 1984; Saczynska et al., 1993), although not in all populations (Rietze, 1988; Staub, 1988).

Smeets and Wehner (1997) developed a method for screening seedlings of cucumber using specific environmental conditions and cultigens that were tolerant (AR75-79, 'Chipper', 'Pixie', and 'Wisconsin SMR 18') or susceptible (Gy14, 'Marketmore 76', NCSU M28, NCSU M29, and 'Poinsett 76'). They concluded that genetic variation for chilling damage was greater at the first true leaf than at the cotyledon stage. Using this method, comparisons of cultigens for their tolerance to low temperatures during the seedling stage of development in cucumber have been reported. Chung et al. (2003) investigated inheritance of CI in progenies of both tolerant
'Chipper' and AR75-79 crossed with susceptible Gy14. Their data suggested that chilling tolerance was maternally inherited. Wehner and Kozik (2007) also demonstrated that there was low heritability for chilling tolerance in two cucumber populations that were developed from elite cultivars not chosen for chilling tolerance. A later screening of the cucumber germplasm collection resulted in the identification of a high level of tolerance of PI 246930. Genetic studies in cucumber inbred NC-76 (developed from PI 246930) showed that chilling tolerance was the result of a single, dominant, nuclear gene $C h$ (Kozik and Wehner, 2008).

Sensitivity of watermelon fruit to CI has been studied by Risse et al. (1990), but chilling tolerance of watermelon plants has not been reported. Because efficient testing methods have been developed for screening cucumber cultigens for tolerance to chilling, it may be possible to adapt such methods for investigation of resistant watermelon cultigens and the inheritance of chilling tolerance for plant improvement. Therefore, a study was designed to develop an efficient testing method for chilling tolerance in watermelon and to use that method to identify chilling-resistant cultigens.

\section{Materials and Methods}

Plant material. Sixteen cultigens were chosen on the basis of genetic diversity for horticultural traits: Allsweet, Black Diamond, Chubby Gray, Charlee, Charleston Gray, Dixielee, Golden, Golden Honey, New Winter, NH Midget, Sugar Baby, Sugarlee, Sunshade, PI 189225 (Zaire), PI 244018 (South Africa), and PI 595203 (Nigeria).

Seeds were sown in peat pots $(57 \mathrm{~mm}$ square, $100 \mathrm{~mL}$ volume) filled with a standard substrate of gravel and peat in a 1:1 ratio and placed in flats. One seed was sown in each pot with 54 pots contained in each flat. After seeding the flats were placed in growth chambers set at $26 / 22{ }^{\circ} \mathrm{C}$ (day/night) temperatures under long days, consisting of $12 \mathrm{~h}$ of combined fluorescent $\left(650 \mathrm{mmol} \cdot \mathrm{m}^{-2} \cdot \mathrm{s}^{-1}\right)$ and incandescent $\left(44 \mathrm{mmol} \cdot \mathrm{m}^{-2} \cdot \mathrm{s}^{-1}\right)$ light (from 0800 to $2000 \mathrm{HR}$ ). Plants were watered to saturation with a standard phytotron nutrient solution (Thomas et al., 2005).

Chilling treatments. Experiments were conducted under controlled environment conditions in the growth chambers of the Phytotron of the Southeastern Plant Environment Laboratory at North Carolina State University (Thomas et al., 2005). Chilling tests were performed according to the method developed for cucumber seedlings by Smeets and Wehner (1997) with some modifications. After the plants reached the first true leaf stage, they were moved from the main growth chamber to the chilling chamber for treatment at 2 or $4{ }^{\circ} \mathrm{C}$ under a light intensity of 500 $\mathrm{mmol} \cdot \mathrm{m}^{-2} \cdot \mathrm{s}^{-1} P P F D$ for a duration of 6,12 , 24 , or $36 \mathrm{~h}$. After the chilling treatment, they were returned to the main growth chamber and placed under the same light and temperature regime as before. For each experiment, 
one flat of plants was left unchilled as a control as well as a reference for the rating scale (damage rating of 0 ).

In our experience, it is difficult to maintain uniform treatment conditions when using high light intensity combined with temperature below $2{ }^{\circ} \mathrm{C}$. Therefore, it is easier to get high $\mathrm{CI}$ by using longer chilling duration rather than lower chilling temperature. Although it is unrealistic to have days longer than $15 \mathrm{~h}$, we used chilling duration of $36 \mathrm{~h}$ to develop a chilling test that researchers could actually use in their facilities.

Assessment of injury. The chilling damage was manifested on all of the organs parts (leaves, cotyledons, growing points) as watersoaked patches subsequently turning yellow or necrotic. Plants were rated 7 and $14 \mathrm{~d}$ after chilling for damage on the cotyledons, growing point, and first true leaf for each plant in each plot. The scale used was 0 to 9: $0=$ no damage (based on the unchilled control plants), 1 to $2=$ trace of damage, 3 to $4=$ slight damage ( $20 \%$ to $50 \%$ of tissue necrotic), 5 to $6=$ moderate damage $(50 \%$ to $70 \%$ of tissue necrotic), 7 to $8=$ advanced damage $(70 \%$ to $90 \%$ of tissue necrotic), $9=$ plant dead $(90$ to $100 \%$ tissue necrotic). Data were collected as means overall cotyledons, growing points, and leaves on the plants within each cultigen.

Experiment design and data analysis. Three experiments were conducted using a split-plot treatment arrangement (temperature and duration as whole plot, cultigen as subplot) in a randomized complete block design with four replications (six plants of each cultigen per plot). Data analysis was by the procedure GLM in SAS (SAS/STAT User's Guide, 1988). Means were tested using Fisher's protected least significant difference (F ratio for that treatment significant at the 5\% level).

In Expt. 1, the effect of a chilling treatment of 6,12 , or $24 \mathrm{~h}$ at 2 or $4{ }^{\circ} \mathrm{C}$ was studied. In Expt. 2, durations of 12, 24, or $36 \mathrm{~h}$ of chilling at 2 or $4{ }^{\circ} \mathrm{C}$ were used. In Expt. 3, the effect of a chilling treatment of 24 or $36 \mathrm{~h}$ at 2 or $4{ }^{\circ} \mathrm{C}$ was studied.

\section{Results and Discussion}

In each of the three experiments, damage ratings on Days 7 and 14 after chilling were highly correlated (data not shown). Because damage had not developed fully on Day 7, damage on Day 14 was used as the measure of chilling tolerance for the cultigens (data not shown).

In Expt. 1, there was little chilling damage at 6- and 12-h duration at both temperatures (Table 1). Therefore, in Expt. 2 (Table 2), we added a 36-h duration to increase chilling damage among the cultigens tested. Because we got the best results in chilling damage from 24- and 36-h duration in Expt. 2, the third experiment was run using those treatments and a larger number of cultigens (Table 3 ).

Expt. 1. Chilling duration and chilling temperature affected watermelon foliage damage. Chilling damage increased as chilling duration increased and chilling temperature
Table 1. Seedling damage from 4 and $2{ }^{\circ} \mathrm{C}$ chilling temperatures and 6,12 , and $24 \mathrm{~h}$ chilling durations on chilling damage in seedlings of seven watermelon cultigens in Expt. 1. ${ }^{2}$

\begin{tabular}{|c|c|c|c|c|c|c|c|c|c|}
\hline \multirow[b]{2}{*}{ Cultigen } & \multicolumn{3}{|c|}{ 6-h duration } & \multicolumn{3}{|c|}{ 12-h duration } & \multicolumn{3}{|c|}{ 24-h duration } \\
\hline & $\overline{\mathrm{GP}^{y}}$ & $\mathrm{Lf}^{\mathrm{x}}$ & $\mathrm{Ct}^{\mathrm{w}}$ & $\overline{\text { GPy }^{y}}$ & $\mathrm{Lf}^{\mathrm{x}}$ & $\mathrm{Ct}^{\mathrm{w}}$ & $\mathrm{GP}^{\mathrm{y}}$ & $\mathrm{Lf}^{\mathrm{x}}$ & $\mathrm{Ct}^{\mathrm{w}}$ \\
\hline \multicolumn{10}{|l|}{$4^{\circ} \mathrm{C}$ chilling temp } \\
\hline Allsweet & 0.0 & 0.3 & 0.8 & 0.0 & 1.8 & 2.2 & 1.0 & 3.0 & 3.5 \\
\hline Black Diamond & 0.0 & 0.8 & 0.2 & 0.3 & 2.7 & 0.7 & 0.8 & 3.7 & 3.3 \\
\hline Charleston Gray & 0.7 & 1.0 & 0.0 & 0.7 & 2.8 & 1.7 & 1.8 & 5.2 & 4.2 \\
\hline PI 244018 & 0.0 & 1.0 & 1.0 & 0.0 & 2.3 & 0.8 & 0.0 & 1.2 & 8.0 \\
\hline PI 595203 & 1.2 & 1.3 & 0.0 & 1.8 & 5.0 & 0.7 & 1.0 & 6.2 & 3.0 \\
\hline Dixielee & 0.0 & 1.3 & 1.0 & 1.3 & 2.2 & 3.2 & 0.8 & 3.7 & 4.0 \\
\hline NH Midget & 0.2 & 1.5 & 1.0 & 1.3 & 2.8 & 1.2 & 1.3 & 4.8 & 3.8 \\
\hline Mean & 0.3 & 1.0 & 0.6 & 0.8 & 2.8 & 1.5 & 1.0 & 4.0 & 4.3 \\
\hline Minimum & 0.0 & 0.3 & 0.0 & 0.0 & 1.8 & 0.7 & 0.0 & 1.2 & 3.0 \\
\hline Maximum & 1.2 & 1.5 & 1.0 & 1.8 & 5.0 & 3.2 & 1.8 & 6.2 & 8.0 \\
\hline Range & 1.2 & 1.2 & 1.0 & 1.8 & 3.2 & 2.5 & 1.8 & 5.0 & 5.0 \\
\hline $\operatorname{LSD}(5 \%)$ & 0.5 & 0.8 & 0.6 & 1.0 & 1.2 & 0.9 & 1.1 & 1.3 & 1.4 \\
\hline \multicolumn{10}{|l|}{$2^{\circ} \mathrm{C}$ chilling temp } \\
\hline Allsweet & 0.3 & 1.3 & 0.8 & 1.0 & 4.3 & 4.5 & 0.7 & 7.5 & 6.8 \\
\hline Black Diamond & 0.2 & 0.8 & 0.8 & 1.0 & 3.2 & 4.2 & 2.3 & 6.3 & 6.2 \\
\hline Charleston Gray & 0.0 & 1.3 & 1.7 & 1.7 & 3.8 & 3.7 & 2.2 & 6.7 & 6.8 \\
\hline PI 244018 & 0.0 & 0.0 & 0.0 & 0.0 & 3.0 & 4.0 & 0.0 & 1.0 & 6.0 \\
\hline PI 595203 & 0.2 & 2.3 & 0.0 & 1.2 & 4.8 & 2.5 & 2.0 & 7.7 & 6.2 \\
\hline Dixielee & 1.0 & 3.0 & 1.0 & 0.0 & 1.0 & 8.0 & 2.2 & 6.2 & 6.0 \\
\hline NH Midget & 1.0 & 2.5 & 2.3 & 1.2 & 4.2 & 7.3 & 2.3 & 6.5 & 7.7 \\
\hline Mean & 0.4 & 1.6 & 1.0 & 0.9 & 3.5 & 4.9 & 1.7 & 6.0 & 6.5 \\
\hline Minimum & 0.0 & 0.0 & 0.0 & 0.0 & 1.0 & 2.5 & 0.0 & 1.0 & 6.0 \\
\hline Maximum & 1.0 & 3.0 & 2.3 & 1.7 & 4.8 & 8.0 & 2.3 & 7.7 & 7.7 \\
\hline Range & 1.0 & 3.0 & 2.3 & 1.7 & 3.8 & 5.5 & 2.3 & 6.7 & 1.7 \\
\hline LSD $(5 \%)$ & 0.6 & 0.9 & 0.7 & 1.0 & 0.9 & 1.6 & 1.2 & 1.9 & 2.0 \\
\hline
\end{tabular}

${ }^{\mathrm{z}}$ Damage rating was 0 to 9: $0=$ no damage, 1 to $2=$ trace of damage, 3 to $4=$ slight damage, 5 to $6=$ moderate damage, 7 to $8=$ advanced damage, $9=$ plant dead.

${ }^{\mathrm{y}}$ Growing point

${ }^{\mathrm{x}}$ Leaf.

${ }^{\mathrm{w}}$ Cotyledons.

LSD = least significant difference.

Table 2. Effect of 4 and $2{ }^{\circ} \mathrm{C}$ chilling temperatures and 12, 24, and $36 \mathrm{~h}$ chilling durations on chilling damage in seedlings of seven watermelon cultigens in Expt. 2. ${ }^{z}$

\begin{tabular}{|c|c|c|c|c|c|c|c|c|c|}
\hline \multirow[b]{2}{*}{ Cultigen } & \multicolumn{3}{|c|}{ 12-h duration } & \multicolumn{3}{|c|}{ 24-h duration } & \multicolumn{3}{|c|}{ 36-h duration } \\
\hline & $\mathrm{GP}^{\mathrm{y}}$ & $\mathrm{Lf}^{\mathrm{x}}$ & $\mathrm{Ct}^{\mathrm{w}}$ & $\mathrm{GP}^{\mathrm{y}}$ & $\mathrm{Lf}^{\mathrm{x}}$ & $\mathrm{Ct}^{\mathrm{w}}$ & $\mathrm{GP}^{\mathrm{y}}$ & $L f^{x}$ & $\mathrm{Ct}^{\mathrm{w}}$ \\
\hline \multicolumn{10}{|l|}{$4^{\circ} \mathrm{C}$ chilling temp } \\
\hline Allsweet & 0.0 & 2.3 & 1.0 & 1.8 & 5.2 & 3.3 & 0.8 & 7.3 & 5.0 \\
\hline Black Diamond & 0.0 & 2.0 & 1.0 & 1.5 & 5.0 & 3.0 & 2.5 & 7.3 & 5.3 \\
\hline Charleston Gray & 0.5 & 2.7 & 1.3 & 1.3 & 4.7 & 3.8 & 2.5 & 8.0 & 3.8 \\
\hline PI 244018 & 0.0 & 0.0 & 2.0 & 0.0 & 0.0 & 3.0 & 0.0 & 2.0 & 8.5 \\
\hline PI 595203 & 1.0 & 3.7 & 1.3 & 1.8 & 4.3 & 1.3 & 3.2 & 7.5 & 3.7 \\
\hline Dixielee & 0.0 & 1.0 & 0.0 & 0.2 & 5.3 & 2.2 & 2.2 & 8.2 & 8.2 \\
\hline NH Midget & 0.5 & 4.5 & 1.8 & 2.2 & 5.7 & 5.0 & 2.3 & 9.0 & 8.7 \\
\hline Mean & 0.3 & 2.3 & 1.2 & 1.3 & 4.3 & 3.1 & 1.9 & 7.0 & 6.2 \\
\hline Minimum & 0.0 & 0.0 & 0.0 & 0.0 & 0.0 & 1.3 & 0.0 & 2.0 & 3.7 \\
\hline Maximum & 1.0 & 2.5 & 2.0 & 2.2 & 5.7 & 5.0 & 3.2 & 9.0 & 8.7 \\
\hline Range & 1.0 & 2.5 & 2.0 & 2.2 & 5.7 & 3.7 & 3.2 & 7.0 & 5.0 \\
\hline LSD $(5 \%)$ & 0.4 & 1.0 & 1.1 & 1.1 & 1.3 & 0.9 & 1.3 & 2.1 & 2.2 \\
\hline \multicolumn{10}{|l|}{$2{ }^{\circ} \mathrm{C}$ chilling temp } \\
\hline Allsweet & 0.0 & 4.3 & 1.0 & 1.3 & 5.7 & 4.3 & 9.0 & 9.0 & 9.0 \\
\hline Black Diamond & 0.7 & 4.2 & 1.7 & 1.0 & 7.8 & 4.7 & 9.0 & 9.0 & 9.0 \\
\hline Charleston Gray & 0.8 & 4.7 & 3.2 & 1.2 & 7.2 & 4.8 & 9.0 & 9.0 & 9.0 \\
\hline PI 244018 & 0.0 & 3.0 & 4.0 & 0.7 & 3.8 & 6.7 & 9.0 & 9.0 & 9.0 \\
\hline PI 595203 & 1.3 & 5.7 & 2.0 & 1.3 & 6.5 & 4.3 & 8.2 & 9.0 & 9.0 \\
\hline Dixielee & 1.0 & 2.8 & 1.3 & 1.0 & 7.2 & 3.2 & 9.0 & 9.0 & 9.0 \\
\hline NH Midget & 0.8 & 5.2 & 4.5 & 1.5 & 6.0 & 5.8 & 9.0 & 9.0 & 9.0 \\
\hline Mean & 0.7 & 4.3 & 2.5 & 1.1 & 6.7 & 4.8 & 8.9 & 9.0 & 9.0 \\
\hline Minimum & 0.0 & 2.8 & 1.0 & 0.7 & 5.7 & 3.2 & 8.2 & 9.0 & 9.0 \\
\hline Maximum & 1.3 & 5.7 & 4.5 & 1.5 & 7.8 & 6.7 & 9.0 & 9.0 & 9.0 \\
\hline Range & 1.3 & 2.9 & 3.5 & 0.8 & 2.1 & 3.5 & 0.8 & 0.0 & 0.0 \\
\hline $\operatorname{LSD}(5 \%)$ & 0.9 & 1.7 & 1.2 & 0.7 & 1.9 & 1.2 & 0.4 & - & - \\
\hline
\end{tabular}

${ }^{2}$ Damage rating was 0 to $9: 0=$ no damage, 1 to $2=$ trace of damage, 3 to $4=$ slight damage, 5 to $6=$ moderate damage, 7 to $8=$ advanced damage, $9=$ plant dead.

${ }^{\mathrm{y}}$ Growing point.

${ }^{x}$ Leaf.

${ }^{\mathrm{w}}$ Cotyledons.

LSD $=$ least significant difference. 
Table 3. Effect of 2 and $4{ }^{\circ} \mathrm{C}$ chilling temperature and 24- and 36-h chilling duration on chilling damage in seedlings of 10 watermelon cultigens in Expt. 3. ${ }^{z}$

\begin{tabular}{|c|c|c|c|c|c|c|}
\hline \multirow[b]{2}{*}{ Cultigen } & \multicolumn{3}{|c|}{ 24-h duration at $2{ }^{\circ} \mathrm{C}$} & \multicolumn{3}{|c|}{ 36-h duration $4{ }^{\circ} \mathrm{C}$} \\
\hline & $\mathrm{GP}^{\mathrm{y}}$ & $\mathrm{Lf}^{\mathrm{x}}$ & $\mathrm{Ct}^{\mathrm{w}}$ & $\mathrm{GP}^{\mathrm{y}}$ & $\operatorname{Lf}^{x}$ & $\mathrm{Ct}^{\mathrm{w}}$ \\
\hline Chubby Gray & 1.6 & 4.9 & 5.1 & 0.5 & 4.8 & 6.8 \\
\hline PI 595203 & 1.3 & 7.0 & 6.0 & 1.1 & 5.6 & 6.6 \\
\hline PI 189225 & 0.5 & 4.4 & 5.6 & 1.3 & 5.6 & 6.8 \\
\hline Sunshade & 0.7 & 4.8 & 3.9 & 0.2 & 4.4 & 4.7 \\
\hline Sugarlee & 0.9 & 5.2 & 3.3 & 0.5 & 6.8 & 2.7 \\
\hline Golden & 0.3 & 8.0 & 7.9 & 0.2 & 7.0 & 6.3 \\
\hline Charlee & 0.1 & 5.3 & 3.5 & 0.0 & 3.2 & 3.8 \\
\hline New Winter & 0.4 & 6.7 & 4.4 & 0.3 & 5.6 & 5.0 \\
\hline Golden Honey & 3.2 & 6.9 & 7.8 & 0.0 & 6.2 & 6.3 \\
\hline Sugar Baby & 1.1 & 6.9 & 6.8 & 0.7 & 7.4 & 6.9 \\
\hline Mean & 1.0 & 6.0 & 5.4 & 0.5 & 5.7 & 5.6 \\
\hline Minimum & 0.1 & 4.4 & 3.3 & 0.0 & 3.2 & 2.7 \\
\hline Maximum & 3.2 & 8.0 & 7.9 & 1.3 & 7.4 & 6.9 \\
\hline Range & 3.1 & 3.6 & 4.6 & 1.3 & 4.2 & 4.2 \\
\hline $\operatorname{LSD}(5 \%)$ & 0.6 & 1.7 & 1.5 & 0.9 & 1.7 & 1.7 \\
\hline
\end{tabular}

zDamage rating was 0 to $9: 0=$ no damage, 1 to $2=$ trace of damage, 3 to $4=$ slight damage, 5 to $6=$ moderate damage, 7 to $8=$ advanced damage, $9=$ plant dead.

${ }^{\mathrm{y}}$ Growing point.

${ }^{\mathrm{x}}$ Leaf.

${ }^{\mathrm{w}}$ Cotyledons.

LSD $=$ least significant difference.

decreased (Table 1). At both chilling temperatures $\left(2\right.$ and $\left.4{ }^{\circ} \mathrm{C}\right)$, there were shifts in cultigen rank for chilling damage when chilling duration increased (6 to $24 \mathrm{~h}$ ). Chilling damage for all cultigens was highest for the growing point, first true leaf, and cotyledons $(1.7,6.0$, and 6.5 , respectively) after $24 \mathrm{~h}$ of chilling at $2{ }^{\circ} \mathrm{C}$. Damage was greater on the first true leaf and cotyledons than on the growing point, which was somewhat protected in the bud. CI at $2{ }^{\circ} \mathrm{C}$ with 6 to $24 \mathrm{~h}$ of chilling was lowest for PI 244018 for all tissues rated (i.e., growing point, first true leaf, and cotyledons).

Expt. 2. Time of duration $(12,24$, and $36 \mathrm{~h})$ and temperature of chilling $\left(2\right.$ and $\left.4{ }^{\circ} \mathrm{C}\right)$ had a large and significant effect on damage rating. There were shifts in cultigen rank for chilling damage as the duration of chilling was increased and temperature of chilling decreased (Table 2). The differences among cultigens in chilling damage were largest at the 24- and 36-h chilling treatments run at $4{ }^{\circ} \mathrm{C}$. In most of the treatments, chilling damage was lowest on the growing point and higher on the leaves and cotyledons. At the same chilling conditions, values for true leaf and cotyledons were moderate (3.1) to advanced (7.0). The highest chilling damage (mean $=9.0$, all plants dead) was observed when plants were chilled at $2{ }^{\circ} \mathrm{C}$ for $36 \mathrm{~h}$; there were no differences among cultigens because they were all dead. Similar damage ratings (mean values) for most cultigens were obtained using combinations of $4{ }^{\circ} \mathrm{C}$ with $36 \mathrm{~h}$ and $2{ }^{\circ} \mathrm{C}$ with 24 -h duration.

Expt. 3. In Expt. 3, we used two chilling temperatures $\left(2\right.$ or $4{ }^{\circ} \mathrm{C}$ ) and two chilling durations $(24$ or $36 \mathrm{~h}$ ) with 10 cultigens. Analysis of variance showed that chilling duration and chilling temperature had a significant effect on damage rating (Table 3 ). Mean chilling damage for the cultigens was low for growing point $(0.5$ and 1.0$)$ but moderate for true leaves (5.7 and 6.0) and cotyledons (5.1 and 5.5). Thus, differences among cultigens were larger for the first true leaf and cotyledons than for growing point. The rank of cultigen for chilling tolerance in Expt. 3 was fairly consistent for damage of true leaf and cotyledons.

Effect of chilling temperature and chilling duration on watermelon seedlings was tested in our experiments to develop an efficient method and to use that method to identify chilling tolerant cultigens. Mean chilling damage increased with an increase in the duration of chilling and a decrease of temperature during chilling. Mean chilling damage was lowest when the plants were subjected to treatment combinations of 4 or $2{ }^{\circ} \mathrm{C}$ temperatures for 6 - or 12-h durations, and there were no distinct differences among cultigens (Table 1). Chilling damage increased significantly when the plants were exposed to 4 and $2{ }^{\circ} \mathrm{C}$ for 24 and $36 \mathrm{~h}$ (Tables 2 and 3 ). The largest differences among cultigens were detected at treatment combinations of $4{ }^{\circ} \mathrm{C}$ with $36 \mathrm{~h}$ and $2{ }^{\circ} \mathrm{C}$ with $24 \mathrm{~h}$. The greatest chilling damage (all plants dead) was observed when plants were chilled at $2{ }^{\circ} \mathrm{C}$ for $36 \mathrm{~h}$.

Compared with leaf and cotyledon damage, there was less effect of chilling temperature and chilling duration on growing point damage. Even so, there were significant differences among cultigens for chilling tolerance of the growing point damage. In our experience, seedlings will recover from $\mathrm{CI}$ if the growing point has a damage rating lower than 6 , although growth may be delayed. Additional research is needed to determine what level of damage is sustainable and when growers would need to replant their crop after a chilling event.

Exposure of cucumber seedlings to $4{ }^{\circ} \mathrm{C}$ for $7 \mathrm{~h}$ is an effective method for testing tolerance to chilling (Kozik and Wehner, 2008; Smeets and Wehner, 1997). However, watermelon plants needed a test having a longer duration chilling ( 24 or $36 \mathrm{~h}$ ) to differentiate the cultigens tested. Thus, watermelon seedlings are more tolerant to chilling than cucumber seedlings.
In conclusion, watermelon seedlings can be efficiently tested for tolerance to chilling using controlled environment chambers with a light intensity of $500 \mathrm{mmol} \cdot \mathrm{m}^{-2} \cdot \mathrm{s}^{-1} P P F D$. Seedlings should be chilled for $36 \mathrm{~h}$ at $4{ }^{\circ} \mathrm{C}$ or $24 \mathrm{~h}$ at $2{ }^{\circ} \mathrm{C}$ for best results. The cultigens tested in this study were mostly susceptible. Those with the most tolerance were PI 244018 and 'Charlee' and those with the most susceptibility were 'NH Midget' and 'Golden'. Additional research is needed to determine the inheritance of tolerance of watermelon seedlings to chilling temperatures.

\section{Literature Cited}

Aoki, S., M. Oda, and K. Hosino. 1989. Varietal differences in chilling-induced depression of photosynthesis and leaf growth in cucumber seedlings. J. Jpn. Soc. Hort. Sci. 58:173-179.

Aoki, S., M. Oda, and M. Nagaoka. 1988. Chilling and heat sensitivities in cucumber seedlings measured by chlorophyll fluorescence. Bull. Nat. Res. Inst. Veg., Ornam. Plants \& Tea Japan. Ser. A 2:81-92.

Arney, M., S.R. Fore, and R. Brancucci. 2006 Watermelon reference book. National Watermelon Promotion Board.

Cabrera, R.M., M.E. Saltveit, and K. Owens. 1992. Cucumber cultivars differ in their response to chilling temperatures. J. Amer. Soc. Hort. Sci. 117:802-807.

Chung, S.-M., J.E Staub, and G Fazio. 2003. Inheritance of chilling injury: A maternally inherited trait in cucumber. J. Amer. Soc. Hort. Sci. 128:526-530.

Kozik, E.U., U. Klosinska, and T.C. Wehner. 2007. New sources of chilling resistance in cucumber, p. 227-232. In: Nowaczyk, P. (ed.). Spontaneous and induced variation for the genetic improvement of horticultural crops. University Press, University of Technology and Life Sciences, Bydgoszcz, Poland.

Kozik, E.U. and T.C. Wehner. 2008. A single dominant gene $\mathrm{Ch}$ for chilling resistance in cucumber seedlings. J. Amer. Soc. Hort. Sci. 133:225-227.

Lafuente, M.T., A. Belver, M.G. Guye, and M.E. Saltveit. 1991. Effect of temperature conditioning on chilling injury of cucumber cotyledons. Possible role of abscisic acid and heat shock proteins. Plant Physiol. 95:443-449.

Lasley, S.E., M.P. Garber, and C.F. Hodges. 1979. Aftereffects of light and chilling temperatures on photosynthesis in excised cucumber cotyledons. J. Amer. Soc. Hort. Sci. 104:477480

Liu, H.X., Y.R. Wang, S.X. Zeng, P. Li, Y. Z. Chen, D.F. Chen, and J.Y. Guo. 1984. The effect of chilling stress on respiratory metabolism in cucumber seedlings with different degrees of tolerance. Acta Phytophysiol. Sinica 10:191-199.

Lower, R.L. 1974. Measurement and selection for cold tolerance in cucumber. Pickle Pak Sci. $4: 8-11$.

Lyons, J.M. 1973. Chilling injury in plants. Annu. Rev. Plant Physiol. 24:445-466.

Minchin, A. and E.W. Simon. 1973. Chilling injury in cucumber leaves in relation to temperature. J. Expt. Bot. 24:1231-1235.

Nienhuis, J., R.L. Lower, and J.E. Staub. 1983. Selection for improved low temperature germination in cucumber. J. Amer. Soc. Hort. Sci. 108:1040-1043.

North Carolina Department of Agriculture and Consumer Services. 2004. Agricultural Statistics 
Division. 31 Jan. 2014. <http://www.ncagr. gov/stats/2013AgStat/index.htm>.

Pomeroy, M.K. and J.B. Mudd. 1987. Chilling sensitivity of cucumber cotyledon protoplasts and seedlings. Plant Physiol. 84:677-681.

Raison, J.K. 1974. A biochemical explanation of low temperature stress in tropical and subtropical plants. Bull. R. Soc. N. Z. 12:487-497.

Rietze, E. 1988. Wirkungen kurzfristiger Kälteperioden auf Gurken (Cucumis sativus L.). PhD thesis, University of Hannover, Hannover, Germany. p. 90.

Rietze, E. and H.J. Wiebe. 1987. Kälte im Licht mögen Pflanzen nicht. Deutscher Gartenbau 41:2436-2437.

Rietze, E. and H.J. Wiebe. 1989. Diurnal rhythm of chilling sensitivity of cucumbers in light. Sci. Hort. 38:231-237.

Rikin, A., A. Blumenfeld, and A.E. Richmond. 1976. Chilling resistance as affected by stressing environments and abscisic acid. Bot. Gaz. 137:307-312.

Risse, L.A., J.K. Brecht, S.A. Sargent, S.J. Locascio, J.M. Crall, G.W. Elmstrom, and D.N. Maynard. 1990. Storage characteristics of small watermelon cultivars. J. Amer. Soc. Hort. Sci. 115: 440-443.
Saczynska, V., J. Gemel, and Z. Kaniuga. 1993. Chilling susceptibility of Cucumis species. Phytochemistry 33:61-67.

Saltveit, M.E. 1991. Prior temperature exposure affects subsequent chilling sensitivity. Physiol. Plant. 82:529-536.

SAS/STAT User's Guide. 1988. Release 6.03 edition. SAS Institute, Cary, NC.

Smeets, L. and T.C. Wehner. 1997. Environmental effects on genetic variation of chilling resistance in cucumber. Euphytica 97: 217-225.

Staub, J.E. 1988. Lack of chilling resistance in Cucumis sativus var. hardwickii (R.). Alef. Cucurbit Genet. Coop. Rpt. 11:29-32.

Staub, J.E., R.L. Lower, and J. Nienhuis. 1988. Correlated responses to selection for low temperature germination in cucumber. HortScience 23:745-746.

Thomas, J.F., R.J. Downs, and C.H. Saravitz. 2005. Phytotron procedural manual for controlled environment research at the southeastern plant environment laboratory. NCARS Tech. Bull. 244 (revised).

Van Hasselt, P.R. 1972. Photo-oxidation of leaf pigments in Cucumis leaf discs during chilling. Acta Bot. Neerl. 21:539-548.
Wang, C.Y. 1986. Effects of temperature and light on ACC and MACC in chilled cucumber seedlings. Sci. Hort. 30:47-52.

Wehner, T.C. 1981. Screening for low-temperature germination ability in cucumber. HortScience 16:399 (abstract)

Wehner, T.C. 1982. Genetic variation for lowtemperature germination ability in cucumber. Cucurbit Genet. Coop. Rpt. 5:16-17.

Wehner, T.C. 1984. Estimates of heritabilities and variance components for low-temperature germination ability in cucumber. J. Amer. Soc. Hort. Sci. 109:664-667.

Wehner, T.C. and E.U. Kozik. 2007. Heritability of chilling resistance in seedlings tested from two diverse cucumber populations. Cucurbit Genet. Coop. Rpt. 30:15-19.

Wehner, T.C. and Z.M. Mirdad. 1994. Chilling resistance of five cucurbit species. Cucurbit Genet. Coop. Rpt. 17:38-39.

Wilson, J.M. and R.M.M. Crawford. 1974. Leaf fatty-acid content in relation to hardening and chilling injury. J. Expt. Bot. 25:121131.

Wright, M. and E.W. Wilson. 1973. Chilling injury in cucumber leaves. J. Expt. Bot. 24: 400-411. 